\title{
An NBD Derivative of the Selective Rat Toxicant Norbormide as a New Probe for Living Cell Imaging
}

\section{Claudio D'Amore ${ }^{1 \dagger}$, Genny Orso ${ }^{2 \dagger}$, Fabio Fusi ${ }^{3}$, Mario A. Pagano ${ }^{4}$, Giovanni Miotto ${ }^{5}$, Alessia Forgiarini ${ }^{6}$, Sara De Martin ${ }^{4}$, Giulia Castellani ${ }^{4}$, Giovanni Ribaudo ${ }^{4}$, David Rennison ${ }^{7}$, Margaret A. Brimble ${ }^{7}$, Brian Hopkins ${ }^{7,8}$, Alessandro Ferrarese ${ }^{4}$ and Sergio Bova ${ }^{4 *}$}

\begin{abstract}
${ }^{1}$ Department of Surgical and Biomedical Sciences, University of Perugia, Perugia, Italy, ${ }^{2}$ IRCCS "E. Medea", Conegliano, Italy, ${ }^{3}$ Department of Life Sciences, University of Siena, Siena, Italy, ${ }^{4}$ Department of Pharmaceutical and Pharmacological Sciences, University of Padua, Padua, Italy, ${ }^{5}$ Department of Molecular Medicine, University of Padua, Padua, Italy, ${ }^{6}$ stituto di Ricerca Pediatrica Città della Speranza, Padua, Italy, ${ }^{7}$ School of Chemical Sciences, University of Auckland, Auckland, New Zealand, ${ }^{8}$ Landcare Research, Lincoln, New Zealand
\end{abstract}

OPEN ACCESS

Edited by:

Alfonso Pompella,

University of Pisa, Italy

Reviewed by:

Richard Anthony DeFazio,

University of Michigan, USA

Hongyan Sun,

City University of Hong Kong

China

*Correspondence:

Sergio Bova

sergio.bova@unipd.it

${ }^{\dagger}$ These authors have contributed equally to this work.

Specialty section:

This article was submitted to Experimental Pharmacology and Drug

Discovery,

a section of the journal

Frontiers in Pharmacology

Received: 13 July 2016 Accepted: 01 September 2016 Published: 23 September 2016

Citation:

D'Amore C, Orso G, Fusi F, Pagano MA, Miotto G, Forgiarini A, De Martin S, Castellani G, Ribaudo G, Rennison D, Brimble MA, Hopkins B, Ferrarese A and Bova S (2016) An NBD Derivative of the Selective Rat Toxicant Norbormide as a New Probe for Living Cell Imaging. Front. Pharmacol. 7:315. doi: 10.3389/fphar.2016.00315
Norbormide (NRB) is a unique compound that acts directly on rat vascular myocytes to trigger a contractile process, through an as yet unknown mechanism, which results in the selective contraction of rat peripheral arteries. To gain insight into the mechanisms involved in NRB rat-selective activity, we investigated the subcellular distribution of NRB-AF12, a nitrobenzoxadiazole (NBD)-derivative of NRB, in living NRB-sensitive and NRB-insensitive cells. In both cell types, NRB-AF12 localized to the endoplasmic reticulum (ER), Golgi apparatus, mitochondria, lysosomes, and endosomes; however, in NRB-sensitive cells, the fluorescence also extended to the plasma membrane. NRB-AF12 was rapidly internalized into the cells, could easily be washed out and then reloaded back into the same cells, all with a high degree of reproducibility. Cells exposed for $24 \mathrm{~h}$ to NRB-AF12 did not show apparent signs of toxicity, even at concentrations of the dye $(10 \mu \mathrm{M})$ much higher than those required for fluorescence labeling (500 $\eta \mathrm{M})$. The distribution pattern of NRB-AF12 fluorescence was near identical to that of ER-Tracker ${ }^{\circledR}$ (Er-Tr), a fluorescent derivative of glibenclamide, a known $\mathrm{K}_{\text {ATP }}$ channel blocker. Displacement tests did not demonstrate, but at the same time did not rule out the possibility of a common target for ER-Tr, NRB-AF12, NRB, and glibenclamide. On the basis of these results we hypothesize a common target site for NRB-AF12 and ER$\mathrm{Tr}$, and a similar target profile for NRB and glibenclamide, and propose NRB-AF12 as an alternative fluorescence probe to ER-Tracker. Furthermore, NRB-based fluorescence derivatives could be designed to selectively label single cellular structures.

Keywords: norbormide, ER tracker, fluorescent probes, sulphonylurea receptors, LX2 cells

\section{INTRODUCTION}

Norbormide (NRB, see Figure 1A for structure) is a unique vasoactive compound endowed with species-specific vasoconstrictor activity that targets the peripheral blood vessels of the rat (Clarke, 1965; Roszkowski, 1965; Bova et al., 1996). It also provokes a vasorelaxant effect on arteries of several non-rat species, as well as on rat large-caliber vessels (Roszkowski, 1965; Poos et al., 1966; Cavalli et al., 2004). NRB is a mixture of up to eight stereoisomers, four endo-isomers and four 
A

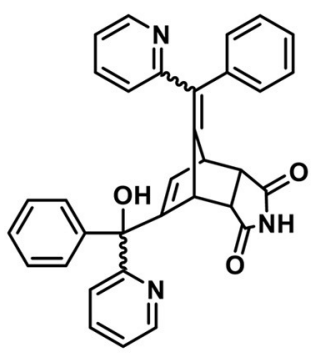

Norbormide
B

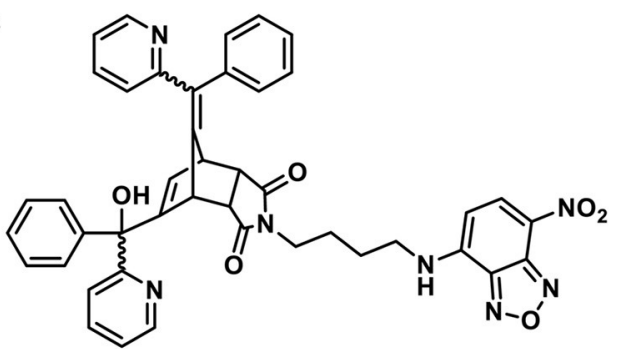

NRB-AF12
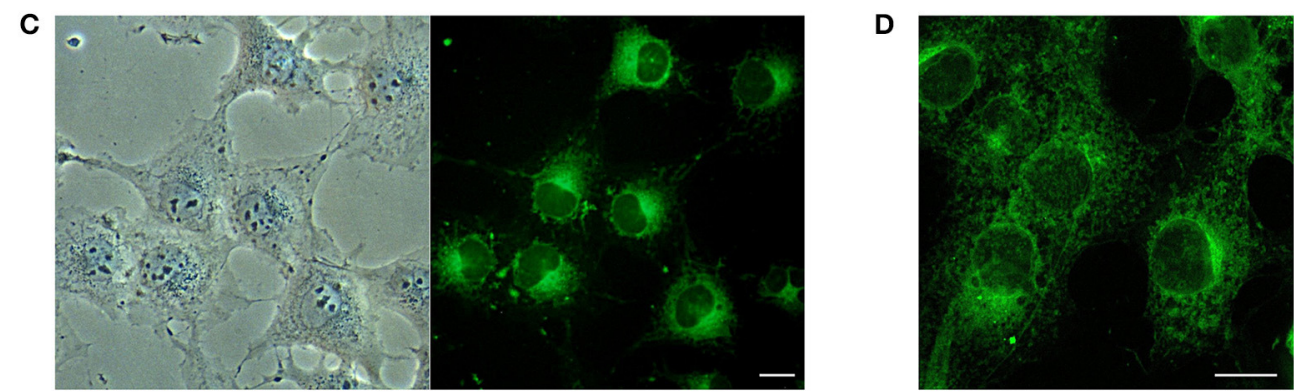

FIGURE 1 | Chemical structures of (A) Norbormide and (B) its fluorescent derivative NRB-AF12. (C) Live cell imaging of LX2 hepatic stellate cells fluorescently labeled with 500 ๆM NRB-AF12 for 30 min. Magnification 40x; scale bar $20 \mu \mathrm{m}$. (D) LX2 cells stained with NRB-AF12 were fixed and imaged by confocal microscopy. Magnification 60x; scale bar $20 \mu \mathrm{m}$.

exo-isomers; among them, only the endo-isomers demonstrate vasocontractile and rat toxicant activities (Poos et al., 1966), whereas both endo- and exo-isomers have vasodilatatory activity in rat aorta and in non-rat arteries (Cavalli et al., 2004). The contractile effect of NRB on rat peripheral blood vessels is endothelium-independent, and is of myogenic nature as confirmed by its action on single rat caudal artery myocytes (Fusi et al., 2002; Cavalli et al., 2004). NRB binding sites and the molecular mechanisms involved in its biological effects in vascular tissue have yet to be fully characterized; it has been proposed that NRB-induced vasoconstriction may result from an interaction with a phospholipase C-coupled receptor (Bova et al., 2001), whereas its relaxant effect may be caused by an inhibitory action on plasma membrane voltage-dependent L-type $\mathrm{Ca}^{2+}$ channels (Fusi et al., 2002). NRB has also been shown to activate the mitochondrial permeability transition pore (mPTP) in isolated rat mitochondria, but not in mitochondria obtained from either guinea-pigs or mice. This suggests that the effect on the mPTP, like NRB-vasoconstriction, is also speciesspecific. However, since this effect could also be induced in mitochondria isolated from different organs of the rat (Ricchelli et al., 2005; Zulian et al., 2007, 2011), unlike vasoconstriction, mPTP activation is not tissue-specific. It is therefore unclear whether NRB-induced activation of the MPTP constitutes a role in the vasoconstrictor effect of NRB.

Correspondingly, addressing the localization of NRB could help characterize the molecular mechanisms underlying the species- and tissue-selective actions of NRB; the original primary objective of this study was therefore to develop a fluorescent derivative of NRB (NRB-AF12, see Figure 1B for structure) in order to compare its subcellular distribution in NRB-sensitive and NRB-insensitive cells. However, since preliminary results indicated a strong overlapping fluorescent distribution between NRB-AF12 and that of ER-Tracker ${ }^{\circledR}$ (ER-Tr), a commercially available fluorescent probe widely used as a selective marker for endoplasmic reticulum (ER), we extended our goals to include a comparison of the staining profiles of the two dyes. The results indicate that NRB-AF12 and ER-Tr show a near identical pattern of fluorescence distribution in both NRB-sensitive and NRBinsensitive cells, and that this fluorescence profile differs between the two cell types. Furthermore, we found that both dyes label not only ER (as would be expected with ER-Tr), but also Golgi apparatus and mitochondria. In addition, unlike ER-Tr, NRBAF12 was also able to label lysosomes and endosomes.

\section{MATERIALS AND METHODS}

\section{Chemistry}

To a solution of endo-NRB $(1.0 \mathrm{~g}, 2.0 \mathrm{mmol})$ in DMF $(6 \mathrm{ml})$ was added $\mathrm{NaH}$ ( $160 \mathrm{mg}, 4.0 \mathrm{mmol}, 60 \% \mathrm{w} / \mathrm{w}$ in oil), and the resulting mixture stirred at room temperature for 15 min, then at $80^{\circ} \mathrm{C}$ for a further $15 \mathrm{~min} \mathrm{~A}$ solution of 4 [(tert-butoxycarbonyl)amino]butyl methanesulfonate (Cao et al., 2016) (0.59 g, $2.2 \mathrm{mmol})$ in DMF ( $2 \mathrm{ml})$ was added, and 
the resulting mixture stirred at $100^{\circ} \mathrm{C}$ for $4 \mathrm{~h}$. The reaction mixture was then allowed to cool, diluted with water and extracted with EtOAc. The separated organic phase was washed with brine, dried over anhydrous $\mathrm{Na}_{2} \mathrm{SO}_{4}$, filtered and the solvent removed in vacuo. Purification by column chromatography (hexane/EtOAc, 1:1) afforded $N-4^{\prime}-[($ tertbutoxycarbonyl)amino] butyl-5-( $\alpha$-hydroxy- $\alpha$-2-pyridylbenzyl)7 -( $\alpha$-2-pyridylbenzylidene)-5-norbornene-2,3-dicarboximide as an endo-exclusive mixture of four stereoisomers (white solid; $1.09 \mathrm{~g}, 1.60 \mathrm{mmol}, 80 \%) .{ }^{1} \mathrm{H}$ NMR (400 MHz, $\left.\mathrm{CDCl}_{3}\right) \delta 1.30-1.68$ $\left(13 \mathrm{H}, \mathrm{m}, \mathrm{C}\left(\mathrm{CH}_{3}\right)_{3}\right.$ and $\left.\mathrm{NCH}_{2} \underline{\mathrm{CH}}_{2} \mathrm{CH}_{2} \mathrm{CH}_{2} \mathrm{NH}\right), 3.05-3.20$ $\left(2 \mathrm{H}, \mathrm{m}, \mathrm{NCH}_{2} \mathrm{CH}_{2} \mathrm{CH}_{2} \mathrm{CH}_{2} \mathrm{NH}\right)$, 3.24-3.70 (4.2H, m, H-2, H-3, $\mathrm{W} / \mathrm{H}-4$ and $\left.\mathrm{NCH}_{2} \mathrm{CH}_{2} \mathrm{CH}_{2} \mathrm{CH}_{2} \mathrm{NH}\right), 3.85-3.90(0.4 \mathrm{H}, \mathrm{m}, \mathrm{U} / \mathrm{H}-1$ and V/H-1), 3.91-3.95 $(0.4 \mathrm{H}, \mathrm{m}, \mathrm{Y} / \mathrm{H}-4), 4.10-4.13(0.1 \mathrm{H}, \mathrm{m}$, $\mathrm{U} / \mathrm{H}-4), 4.26-4.30(0.3 \mathrm{H}, \mathrm{m}, \mathrm{V} / \mathrm{H}-4), 4.42-4.48(0.6 \mathrm{H}, \mathrm{m}, \mathrm{W} / \mathrm{H}-1$ and $\mathrm{Y} / \mathrm{H}-1), 5.55-5.67(1.7 \mathrm{H}, \mathrm{m}, \mathrm{OH}$ and $\mathrm{V} / \mathrm{H}-6$ and $\mathrm{Y} / \mathrm{H}-6)$, 6.02-6.04 (0.1H, m, U/H-6), 6.05-6.07 (0.2H, m, W/H-6), 6.70-7.62 (16H, m, ArH), 8.66-8.39 (2H, m, $\alpha$ Pyr). To a solution of $N$-4'-[(tert-butoxycarbonyl)amino]butyl-5-( $\alpha$-hydroxy- $\alpha-2-$ pyridylbenzyl)-7-( $\alpha$-2-pyridylbenzylidene)-5-norbornene-2,3dicarboximide $(0.34 \mathrm{~g}, 0.5 \mathrm{mmol})$ in DCM $(10 \mathrm{ml})$ was added TFA $(2 \mathrm{ml})$, and the mixture stirred at room temperature for $3 \mathrm{~h}$. The solvent was then removed in vacuo to afford $N$ - $4^{\prime}$-aminobutyl-5( $\alpha$-hydroxy- $\alpha$-2-pyridylbenzyl)-7-( $\alpha$-2-pyridylbenzylidene)-

5 -norbornene-2,3-dicarboximide trifluoroacetate as an endo-exclusive mixture of four stereoisomers [colorless gum (quant.)], which was used without further purification. To a solution of $N$-4'-aminobutyl-5-( $\alpha$-hydroxy- $\alpha$-2-pyridylbenzyl)7-( $\alpha$-2-pyridylbenzylidene)-5-norbornene-2,3-dicarboximide trifluoroacetate $(100 \mathrm{mg}, 0.14 \mathrm{mmol})$ in DCM $(4 \mathrm{ml})$ was added DIPEA ( $73 \mu \mathrm{l}, 0.42 \mathrm{mmol})$, and the mixture stirred at room temperature for $30 \mathrm{~min}$. NBD-Cl (4-chloro-7nitrobenzofurazan) $(28 \mathrm{mg}, 0.14 \mathrm{mmol})$ was added and the resulting mixture stirred at room temperature for a further $6 \mathrm{~h}$. The mixture was then diluted with DCM, washed with saturated aq. $\mathrm{NaHCO}_{3}$, then brine, and the separated organic phase dried over anhydrous $\mathrm{Na}_{2} \mathrm{SO}_{4}$, filtered and the solvent removed in vacuo. Purification by column chromatography (DCM) afforded 5-( $\alpha$-hydroxy- $\alpha$-2-pyridylbenzyl)- $N-4^{\prime}$ $\left[\left(7^{\prime \prime}\right.\right.$-nitro-2" $, 1^{\prime \prime}, 3^{\prime \prime}$-benzoxadiazol-4" -yl)amino $]$ butyl-7- $(\alpha-2-$

pyridylbenzylidene)-5-norbornene-2,3-dicarboximide (NRB$\mathrm{AF} 12)$ as an endo-exclusive mixture of four stereoisomers (orange solid; $50 \mathrm{mg}, 0.067 \mathrm{mmol}, 48 \%$ ). M.p. $108-112^{\circ} \mathrm{C}$; ${ }^{1} \mathrm{H} \quad \mathrm{NMR} \quad\left(400 \mathrm{MHz}, \mathrm{CDCl}_{3} / \mathrm{MeOD} \quad 50: 1 \mathrm{v} / \mathrm{v}\right) \quad \delta \quad 1.61-$ $1.84\left(4 \mathrm{H}, \quad \mathrm{m}, \quad \mathrm{NCH}_{2} \underline{\mathrm{CH}}_{2} \mathrm{CH}_{2} \mathrm{CH}_{2} \mathrm{~N}\right), 3.34-3.73(6.2 \mathrm{H}, \mathrm{m}$, $\mathrm{NCH}_{2} \mathrm{CH}_{2} \mathrm{CH}_{2} \mathrm{CH}_{2} \mathrm{~N}, \mathrm{H}-2, \mathrm{H}-3$ and $\left.\mathrm{W} / \mathrm{H}-4\right), 3.89-3.98(0.7 \mathrm{H}$, $\mathrm{m}, \mathrm{V} / \mathrm{H}-1$ and $\mathrm{Y} / \mathrm{H}-4), 3.99-4.02(0.1 \mathrm{H}, \mathrm{m}, \mathrm{U} / \mathrm{H}-1), 4.18-4.24$ $(0.4 \mathrm{H}, \mathrm{m}, \mathrm{V} / \mathrm{H}-4$ and $\mathrm{U} / \mathrm{H}-4), 4.28-4.38(0.6 \mathrm{H}, \mathrm{m}, \mathrm{Y} / \mathrm{H}-1$ and $\mathrm{W} / \mathrm{H}-1), 5.56-5.62(0.7 \mathrm{H}, \mathrm{m}, \mathrm{V} / \mathrm{H}-6$ and $\mathrm{Y} / \mathrm{H}-6), 6.07-6.09$ (0.1H, m, U/H-6), 6.12-6.14 (0.2H, m, W/H-6), 6.14-6.24 (1H, $\left.\mathrm{m}, \mathrm{H}-5^{\prime \prime}\right), 6.79-7.75$ (16H, m, ArH), 8.37-8.65 (3H, m, $\alpha$ Pyr and H-6").

\section{Fluorescence Spectra of NRB-AF12}

Fluorescence spectra of NRB-AF 12 were obtained by dissolving the dye in water (for details on the methodology see Figure S1 in the Supplementary Material)

\section{Cell Culture}

LX2 (a human immortalized hepatic stellate cell line), HSC-T6 (a rat immortalized hepatic stellate cell line), and HeLa (a human cervical carcinoma cell line) cells were cultured at $37^{\circ} \mathrm{C}$ in an atmosphere of $5 \% \mathrm{CO}_{2}$ in Dulbecco's Modified Eagle Medium (Euroclone - Milan, Italy) supplemented with 10\% Fetal Bovine Serum (Euroclone), 2 mM L-Glutamine and antibiotics. HepG2 cells (a human hepatocarcinoma cell line) were cultured at $37^{\circ} \mathrm{C}$ in an atmosphere of $5 \% \mathrm{CO}_{2}$ in Eagle's Minimum Essential Medium (Euroclone) containing 10\% Fetal Bovine Serum, $2 \mathrm{mM}$ L-Glutamine and antibiotics.

\section{VSMC Isolation}

Smooth muscle cells were freshly isolated from the rat tail main artery under the following conditions: a 5-mm long piece of artery was incubated at $37^{\circ} \mathrm{C}$ for $40-45 \mathrm{~min}$ in $2 \mathrm{ml}$ of $0.1 \mathrm{mM}$ $\mathrm{Ca}^{2+}$ external solution containing $20 \mathrm{mM}$ taurine, $1.35 \mathrm{mg} / \mathrm{ml}$ collagenase (type XI), $1 \mathrm{mg} / \mathrm{ml}$ soybean trypsin inhibitor, and $1 \mathrm{mg} / \mathrm{ml} \mathrm{BSA}$, which was lightly bubbled with a $95 \% \mathrm{O}_{2}-5 \% \mathrm{CO}_{2}$ gas mixture to gently agitate the enzyme solution. Cells were stored in $0.05 \mathrm{mM} \mathrm{Ca}^{2+}$ external solution containing $20 \mathrm{mM}$ taurine and $0.5 \mathrm{mg} / \mathrm{ml} \mathrm{BSA}$ at $4^{\circ} \mathrm{C}$ under normal atmosphere, and were used for experiments within 2 days following isolation (Fusi et al., 2016).

\section{Live-Cell Imaging}

All cell lines tested were stained immediately before imaging. Briefly, cells were trypsinized, counted and seeded in glass bottom $\mu$-Dishes (Ibidi - Munich, Germany) at $2 \times 10^{4}$ cells/dish, and incubated for $24 \mathrm{~h}$ at $37^{\circ} \mathrm{C}$ in an atmosphere of $5 \% \mathrm{CO}_{2}$. Cells were rinsed with Dulbecco's Modified Eagle Medium without phenol red (Euroclone) and loaded with $500 \eta$ M NRB-AF12, $500 \eta \mathrm{M}$ ER-Tr red or green (\#E34250 and \#E34251; Thermo Fisher), and $500 \eta \mathrm{M}$ pHrodo red (\#P10361; Thermo Fisher) at $10 \mu \mathrm{g} / \mathrm{ml}$. In another experiment, LX2 cells were seeded in glass bottom $\mu$-Dishes at $2 \times 10^{4}$ cells $/$ dish and incubated for $24 \mathrm{~h}$ at $37^{\circ} \mathrm{C}$ in an atmosphere of $5 \%$ $\mathrm{CO}_{2}$. Cells were transfected with either 500 ng of MitoDSred or KDEL-red vector using Lipofectamine LTX Reagent (Invitrogen), according to the manufacturer specifications. At 24-h post-transfection, cells were stained with either $500 \eta \mathrm{M}$ NRB-AF12 or $500 \eta \mathrm{M}$ ER-Tr green. Cells were mounted in a Okolab microscope stage heated chamber warmed to $37^{\circ} \mathrm{C}$. All images were collected with a Yokogawa CSU-X1 spinning disk confocal on a Nikon Ti-E inverted microscope equipped with a Plan Apo 60x NA 1.4 objective. Probes were excited with a 488 and $561 \mathrm{~nm}$ Lasers. To separate the individual emissions a dichroic filter 405/488/561/635-25 (Semrock, Rochester, NY) followed by a 440-40/521-21/60734/700-45 filter (Semrock, Rochester, NY) were used and subsequently filtered further using band-pass filters (Semrock BP-525/30-25 and BP-607/36-25 for the green and red channels, respectively). Images were acquired with an Andor Technology iXon3 DU-897-BV EMCCD camera. For time-lapse experiments, images were collected every $10 \mathrm{~s}$, using an exposure time of $500 \mathrm{~ms}$. 


\section{Immunocytochemistry}

To evaluate cell retention of the probe postfixation/permeabilization, LX2 cells $\left(2 \times 10^{4}\right)$ were plated on a $12 \mathrm{~mm}$ glass coverslip placed in a well of a 24 well-plate and incubated for $24 \mathrm{~h}$ at $37^{\circ} \mathrm{C}$ in an atmosphere of $5 \% \mathrm{CO}_{2}$. The cells were then treated with $500 \eta \mathrm{M}$ NRB-AF12 for $30 \mathrm{~min}$, fixed with $4 \%$ paraformaldehyde for $15 \mathrm{~min}$ at room temperature and immediately mounted on microscope slides, or fixed with $4 \%$ paraformaldehyde, permeabilized with either $0.1 \%$ Triton $\mathrm{X}-100$ (10 min at room temperature) or ice cold methanol (5 min at $-20^{\circ} \mathrm{C}$ ), and subsequently mounted.

In order to evaluate NRB-AF12 co-localization with endoplasmic reticulum, Golgi apparatus and with the sulfonylurea receptor (SUR) subunits of the ATP-sensitive potassium channels, cells were fixed with $4 \%$ paraformaldehyde for $15 \mathrm{~min}$ at room temperature, and permeabilized with ice cold methanol for $5 \mathrm{~min}$ at $-20^{\circ} \mathrm{C}$. ER was highlighted with antibodies directed against the ER resident protein calreticulin (1:200; Abcam \#ab2907); Golgi apparatus was highlighted with antibodies directed against the Golgi apparatus structural protein GM130 (1:500; BD Biomedsciences \#610822); SUR2 subunits of
$\mathrm{K}_{\text {ATP }}$ channel were highlighted using either anti-SUR2A (1:750; Abcam \#ab174629) or anti-SUR2B (1:750; Abcam \#ab174631) antibodies. All primary antibodies were incubated for $90 \mathrm{~min}$ at room temperature. Following a PBS wash, cells were incubated with $\mathrm{Cy}^{\mathrm{TM}} 3$ goat anti-rabbit IgG fluorescent secondary antibody (1:500; Jackson ImmunoResearch \#111-165-003) or with $\mathrm{Cy}^{\mathrm{TM}} 3$ goat anti mouse IgG fluorescent secondary antibody (1:500; KPL \#072-01-18-06) for $60 \mathrm{~min}$ at room temperature in the presence of either $500 \eta \mathrm{M}$ NRB-AF12 or $500 \eta \mathrm{M}$ ER-Tr green. Finally, coverslips were mounted on microscope slides using Mowiol 40-88 (Sigma Aldrich). Confocal images were acquired with a Laser Scanning Confocal Microscope (LSCM) D-Eclipse C1 SHV Nikon system equipped with a Nikon Eclipse E600 microscope and 3 laser diode modules (488/543/637 nm), using a CFI Plan Apochromat 60x NA 1.4 objective and analyzed using NIS Elements software (Nikon) and the open-source platform for biological-image analysis Fiji software.

\section{Drosophila melanogaster}

Drosophila strain W[1118], stock number 5905 was obtained from Bloomington stock center (Indiana University, USA)

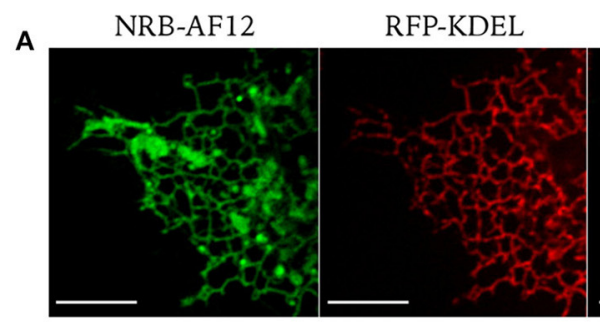

NRB-AF12

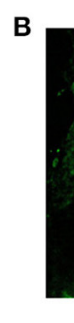

Calreticulin

Calreticulin

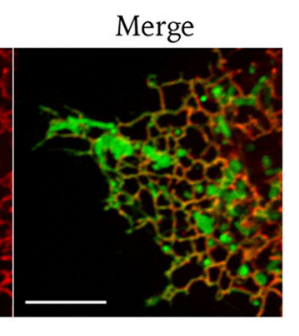

Merge

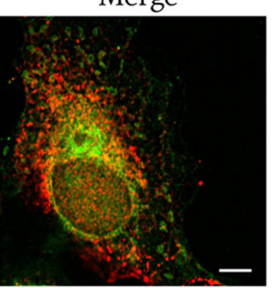

ER Tracker Red

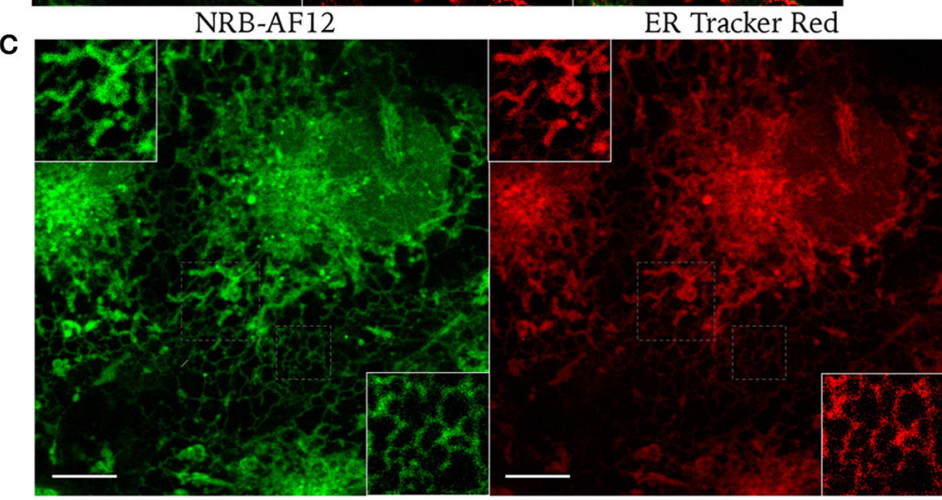

D
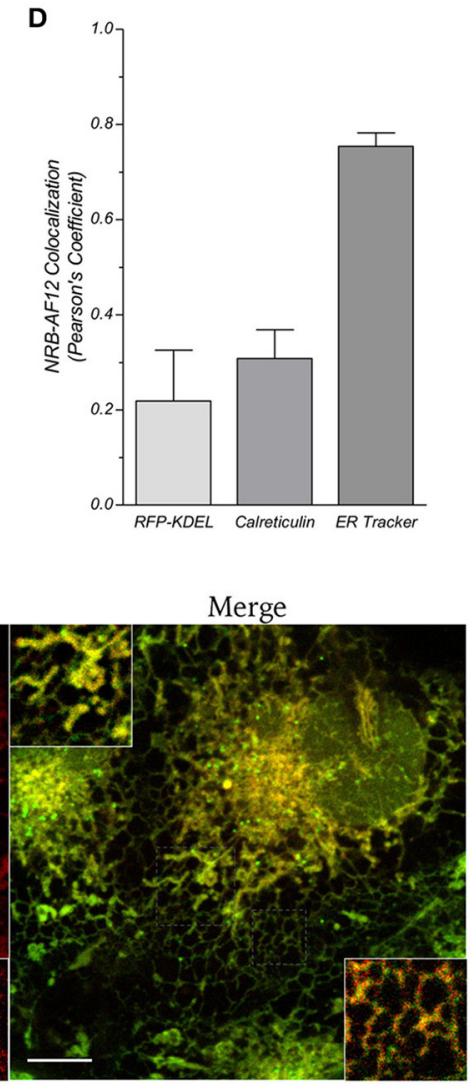

FIGURE 2 | (A) Live cell imaging of LX2 cells transfected with ER-reporter RFP-KDEL plasmid and subsequently stained with NRB-AF12. (B) Immunostaining of LX2 cells for the endoplasmic reticulum marker calreticulin; cells were counter-labeled with NRB-AF12. (C) Confocal live cell imaging of LX2 cells fluorescently labeled with

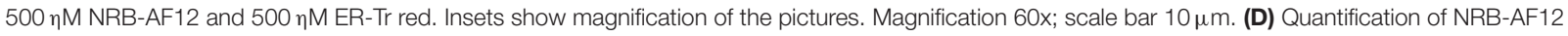
co-localization with RFP-KDEL, Calreticulin and ER-Tr is shown as Pearson's coefficient. ( $n \geq 10$ ). 
and used to perform live imaging experiments. Fly larvae having reached the third instar stage whilst feeding on standard food were dissected in hemolymph-like HL3 saline $(70 \mathrm{mM} \mathrm{NaCl}, 5 \mathrm{mM} \mathrm{KCl}, 1.5 \mathrm{mM} \mathrm{CaCl}, 20 \mathrm{mM}$ $\mathrm{MgCl}_{2}, 10 \mathrm{mM} \mathrm{NaHCO} 3,5 \mathrm{mM}$ trehalose, $115 \mathrm{mM}$ sucrose, $5 \mathrm{mM}$ sodium HEPES, $\mathrm{pH}$ 7.2). For live tissue imaging ER-Tr red and NRB-AF12 were added to the medium of dissected larvae and images acquired using a Nikon eclipse C1 confocal microscope and a Nikon Fluor 60x NA 1.00 water objective.

\section{Biocompatibility}

$1 \times 10^{5}$ LX2 cells, $1 \times 10^{5}$ HepG2 cells and $5 \times 10^{4}$ HSC-T6 cells were plated in 12 well-plates in complete culture medium and incubated for $24 \mathrm{~h}$ at $37^{\circ} \mathrm{C}$. Cells were then treated with increasing doses $(0.1,1$ and $10 \mu \mathrm{M})$ of NRB, NRB-AF12, glibenclamide and ER-Tr for $24 \mathrm{~h}$. Cell viability was assessed by the Trypan Blue exclusion method. Briefly, cells were trypsinized, resuspended in complete medium, diluted 1:2 with a $0.4 \%$ Trypan Blue solution and finally counted using a hemacytometer under a lightmicroscope.

\section{Hazards Related to the Use of NRB and Its Derivatives for Research Purposes}

In HSNO (Hazardous Substances and New Organisms) terms, a substance is considered hazardous if it triggers any one of the threshold levels for any of the hazardous properties listed in the USA Environmental Protection Agency (EPA) guidelines, one of which is toxicity. NRB is extremely toxic to rats and as such is classified as an "extremely hazardous chemical" in the US and elsewhere. However, one of the key features of NRB is that its toxic activity is uniquely limited to rats, having little or no activity in any other species tested (including humans). In fact NRB's lethal activity is even further restricted as it seems only to be toxic to species within the Rattus genus, with other rat genera being little or not affected. As a consequence, the NRB and the NRB derivatives reported in this research paper poses little or no hazard to the researchers, and as such no special conditions or safety precautions are required to work with these substances other than those required to conform to standard laboratory practices.

\section{Statistical Analysis}

All values are expressed as means \pm standard error (SE) of $n$ observations/group. Analysis of co-localization was performed using Pearson's correlation coefficient. Comparisons of more than two groups were made with a one-way ANOVA using post-hoc Tukey's test. Comparison of two groups was obtained by the Student's $t$-test for unpaired data when appropriate. Differences were considered statistically significant at values of $P<0.05$.
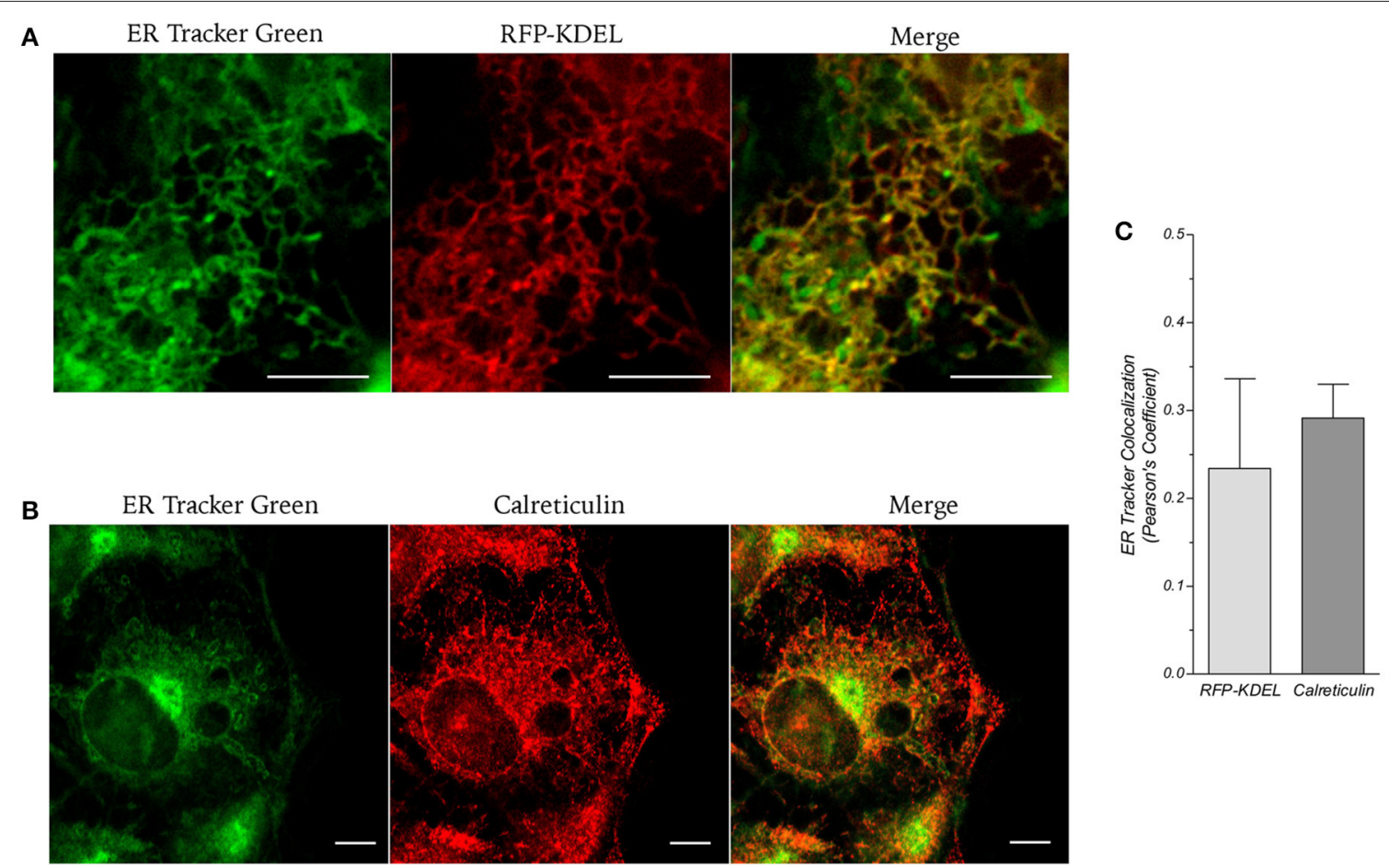

FIGURE 3 | (A) Live cell imaging of LX2 cells transfected with ER-reporter RFP-KDEL plasmid and subsequently stained with ER-Tr. (B) Immunostaining of LX2 cells for the endoplasmic reticulum marker calreticulin; cells were counter-labeled with NRB-AF12. Magnification 60x; scale bar 10 $\mu \mathrm{m}$. (C) Quantification of ER-Tr co-localization with RFP-KDEL and Calreticulin is shown as Pearson's coefficient $(n \geq 10)$. 


\section{RESULTS}

The fluorescence spectra of NRB-AF12 are shown in Figure S1 in Supplementary Material.

The distribution of NRB-AF12 was initially evaluated in NRBinsensitive cells.

Figure 1C shows phase contrast microscopy images and conventional epifluorescence microscopy images of living LX2 cells incubated with $500 \eta \mathrm{M}$ NRB-AF12. The images clearly show a meshwork distribution of the fluorescence with a sharp demarcation of the nuclei and an accumulation in perinuclear areas; moreover, NRB-AF12 did not stain either the nuclei or the plasma membrane. NRB-AF12 internalization into the cell was fast, commencing after only a few seconds and reaching completion within a few minutes, following its addition to the incubation medium. A similar fluorescence pattern was also observed in fixed LX2 cells (Figure 1D), however, the NRB-AF12 signal was not retained post-permeabilization (data not shown). The sub-cellular distribution of NRB-AF12 was investigated in more detail in LX2 cells using confocal microscopy in combination with fluorescent probes and/or antibodies targeted to specific subcellular structures. To evaluate the distribution of NRB-AF12 in the ER, LX2 cells were transfected with the ER-reporter red fluorescent protein (RFP)-KDEL plasmid and subsequently loaded with the dye. The results, reported in Figures 2A,D, show that the NRB-AF12 signal significantly overlapped with that of (RFP)-KDEL (Pearson's Coefficient: $0.21 \pm 0.10 ; n \geq 10$ ), but a larger staining distribution of NRB-AF12 was observed which indicated other targets in addition to ER. Similar results were observed in LX2 fixed cells labeled with NRB-AF12 and immunostained for the ER resident protein Calreticulin (Pearson's Coefficient: $0.3 \pm 0.06 ; n \geq 10$ ) (Figures 2B-D). We also compared the staining pattern of NRBAF12 with that of ER-Tr, a commercial fluorescent probe widely used to label ER. Surprisingly, co-labeling of LX2 cells with NRBAF12 and ER-Tr resulted in a strong overlap between fluorescent dyes (Figure 2C), confirmed by the high rate of co-localization index (Pearson's coefficient: $0.75 \pm 0.02 ; n \geq 15$ ). This remarkable similarity between the two dyes was further supported by the observation that ER-Tr, as well as NRB-AF12, were not selective

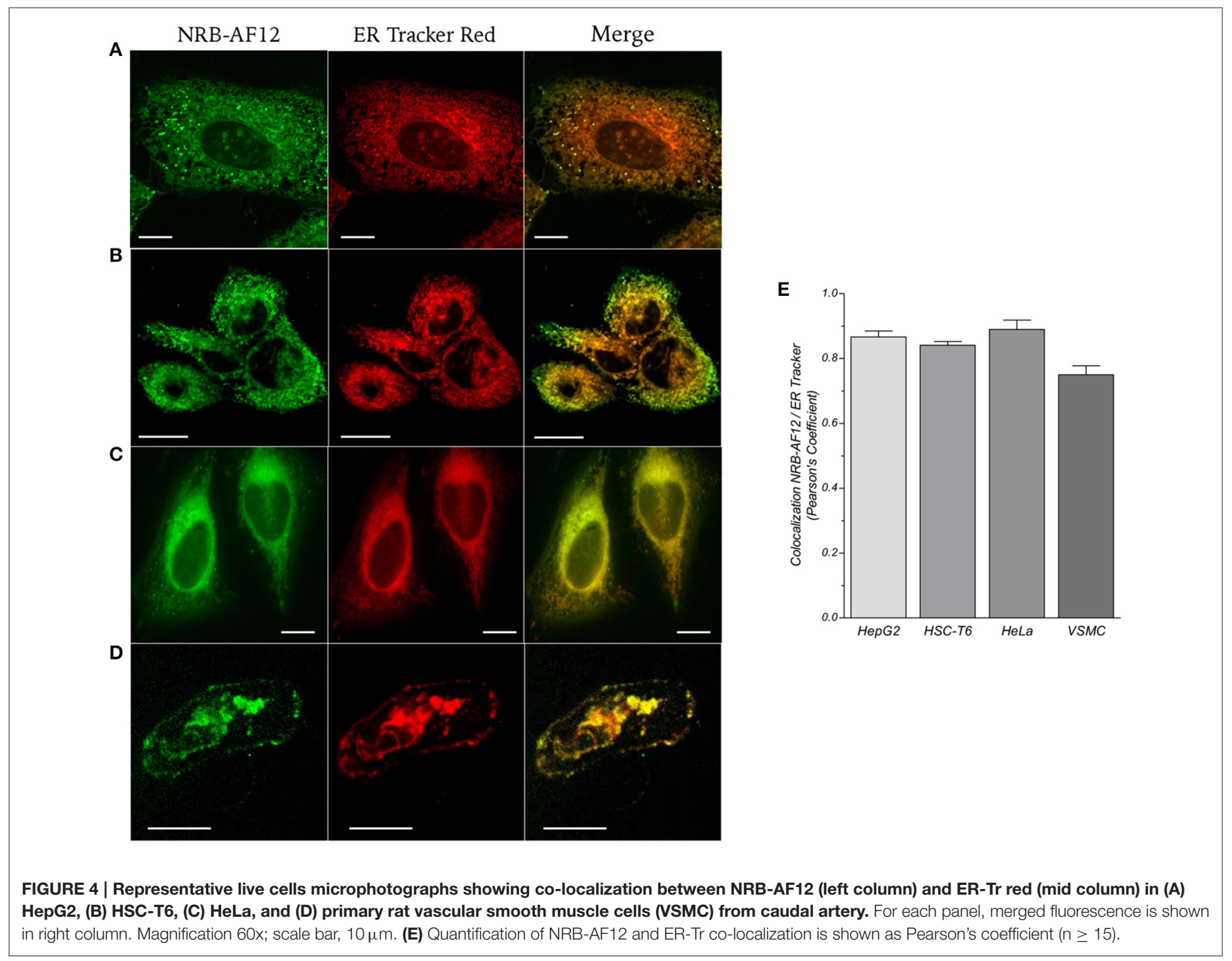




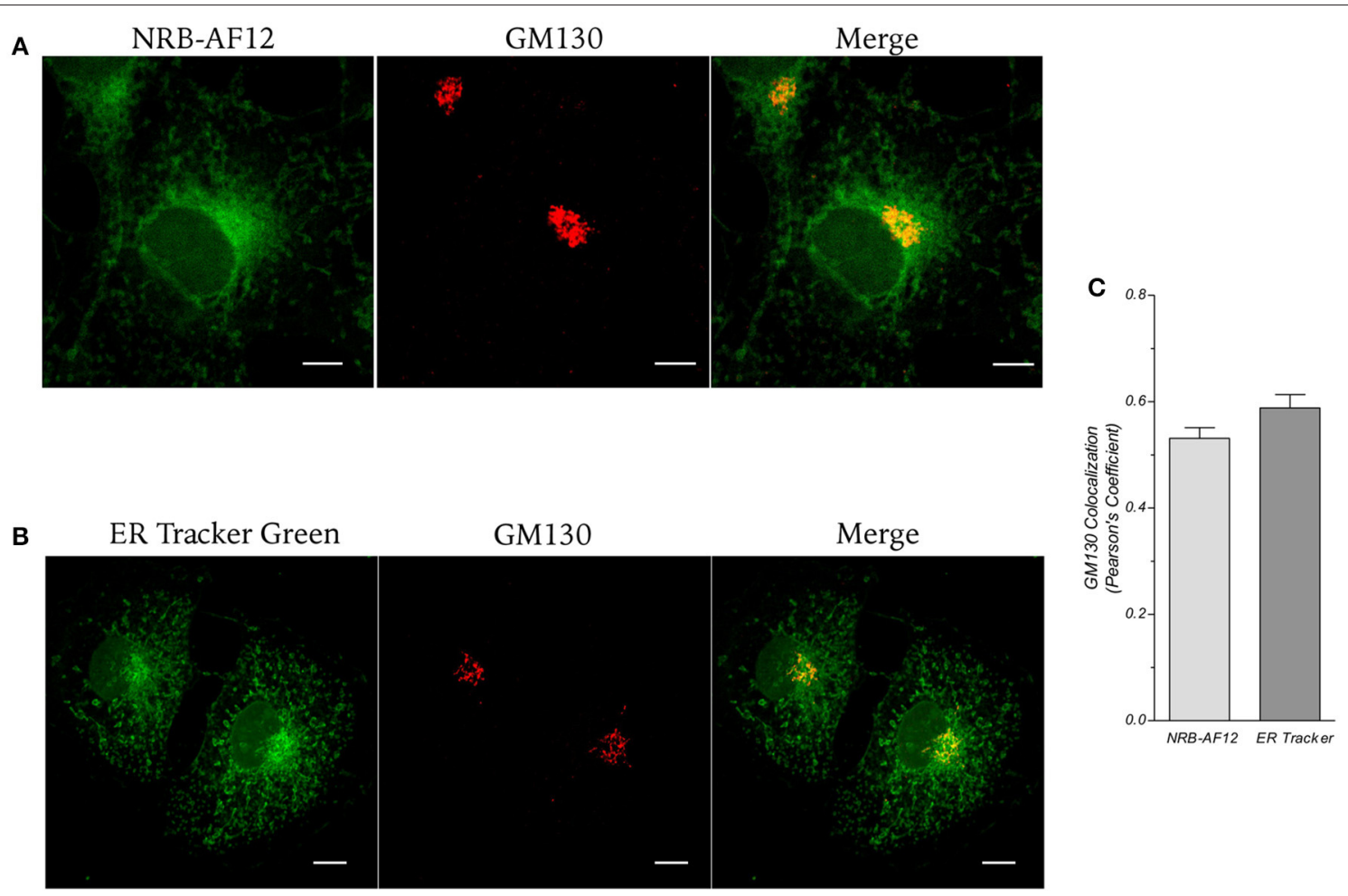

FIGURE 5 | LX2 fixed cells immunostained for the Golgi apparatus structural protein GM130; cells were counter-labeled with (A) NRB-AF12 or (B) ER-Tr green. Magnification 60x; scale bar $10 \mu \mathrm{m}$. (C) Co-localization measure is shown as Pearson's coefficient $(n \geq 10)$.

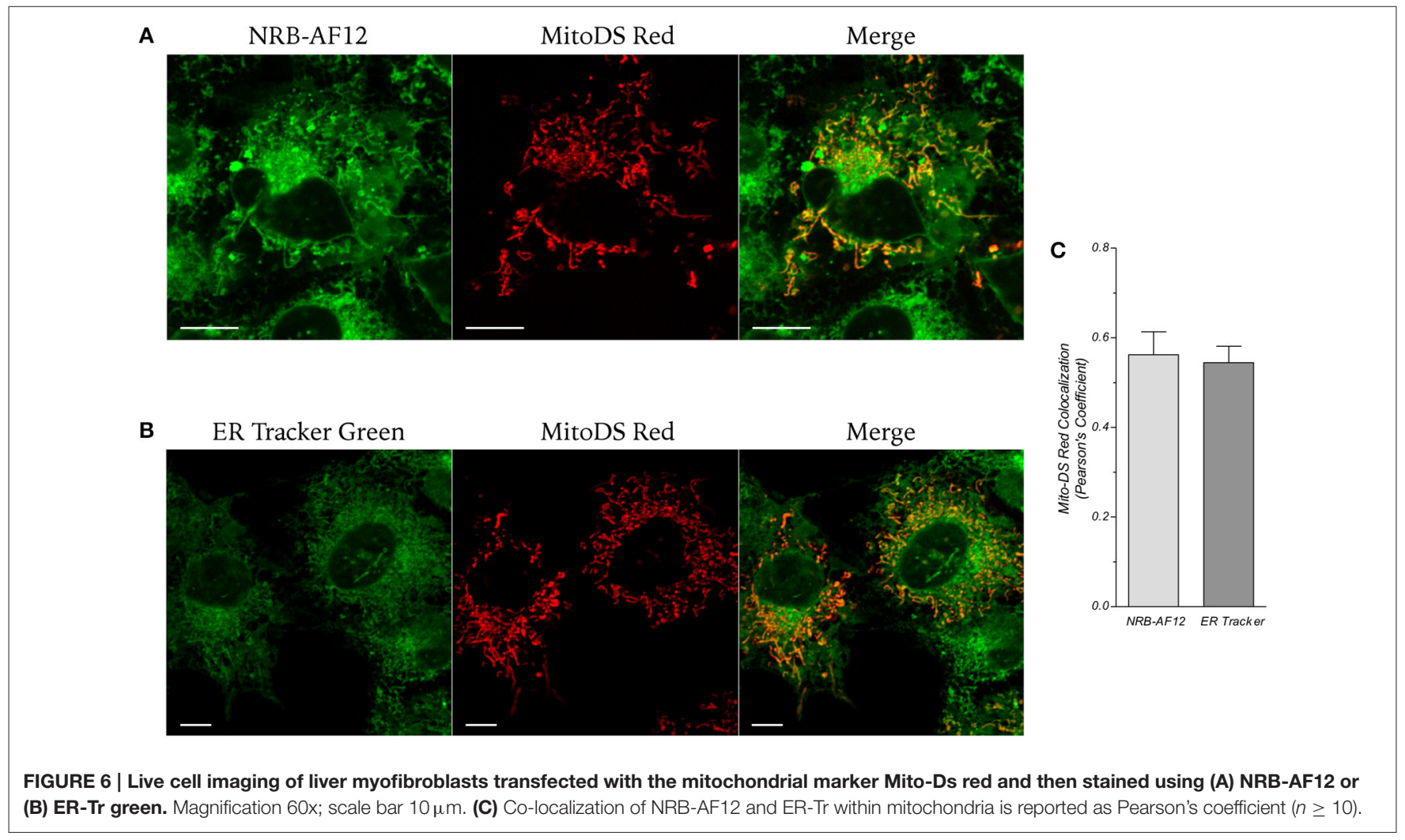


for the ER, as demonstrated by co-staining LX2 cells with ER-Tr plus either RFP-KDEL (Figure 3A) or Calreticulin (Figure 3B) (Pearson's coefficient: $0.23 \pm 0.1$ and $0.29 \pm 0.03$, respectively for RFP-KDEL and Calreticulin; $n \geq 10$; Figure 3C).

The NRB-AF12 and ER-Tr subcellular distribution patterns and co-localization rates were confirmed using other NRBinsensitive cells (i.e., HepG2, HSC-T6, and HeLa cells; Figures 4A-C), and using NRB-sensitive cells such as freshly isolated rat caudal artery myocytes (Figure 4D). Interestingly, in this latter cell type, both fluorescent compounds stained not only intracellular structures, but also the plasma membrane. Co-localization rates of NRB-AF12 and ER-Tr in HepG2, HSC-T6, HeLa and primary rat vascular smooth muscle cells is reported in Figure 4E as Pearson's coefficient. These results indicates that NRB-AF12 labels intracellular structures with a pattern of distribution that is apparently very similar to that of ER-Tr, and is not confined to ER.

We then investigated, using LX2 cells, which non-ER subcellular organelles were labeled by NRB-AF12, and compared the results with those obtained with ER-Tr, focusing our attention on the Golgi apparatus, mitochondria, lysosomes, and endosomes.

The Golgi apparatus was investigated by co-staining fixed cells with either NRB-AF12 or ER-Tr, and antibodies directed against the Golgi structural protein GM130 ( $\alpha$-GM130). Data obtained, shown in Figure 5A, indicates a co-localization of NRB-AF12 and $\alpha$-GM130 (Pearson's coefficient: $0.53 \pm 0.02 ; n$ $\geq 10$; Figure 5C). Similar results were obtained when $\alpha$-GM130 was used in combination with ER-Tr (Pearson's coefficient: 0.58 $\pm 0.02 ; n \geq 10$; Figures 5B,C).

Mitochondrial NRB-AF12 and ER-Tr localization was investigated in living LX2 cells transfected with the mitochondrial marker MitoDS-red plasmid, and then loaded with either NRB-AF12 or ER-Tr. As depicted in Figure 6, both dyes labeled mitochondria to similar levels (Pearson's Coefficient: $0.56 \pm 0.05$ and $0.54 \pm 0.03$, respectively for NRB-AF12 and ER-Tr; $n \geq 10$ ).

Next, we investigated whether NRB-AF12 and ER-Tr could label endosomes and lysosomes. For this purpose, we performed live cell imaging experiments in LX2 cells using a commercial fluorescent probe which has been previously demonstrated to highlight vesicles involved in endocytosis. As shown in Figure 7, we could not find any staining of endocytic vesicles when cells were loaded with ER-Tr (Pearson's coefficient: $-0.33 \pm 0.05$ and $-0.43 \pm 0.04$, respectively for endosomes and lysosomes; $n \geq 10$ ). In contrast, NRB-AF12 showed an appreciable colocalization rate with both endosomal and lysosomal vesicles (Pearson's coefficient $0.25 \pm 0.13$ and $0.15 \pm 0.15$, respectively; $n$ $\geq 10$ ). Interestingly, the data revealed a high index of dispersion of the co-localization coefficients (CI 95\%: $-0.05-0.55$ and

\section{A}
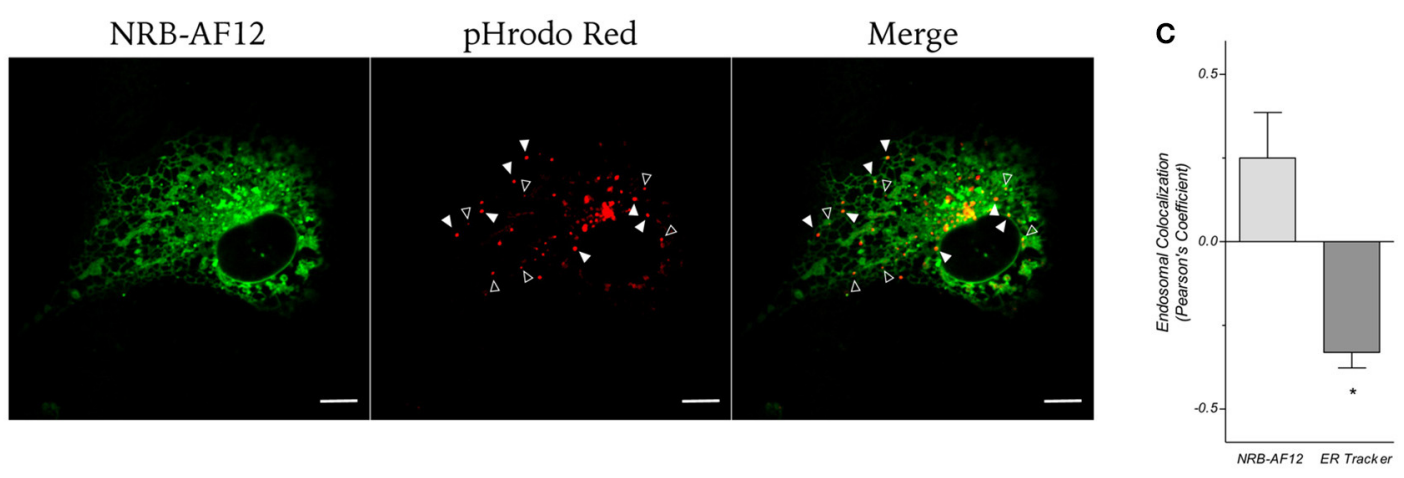

B

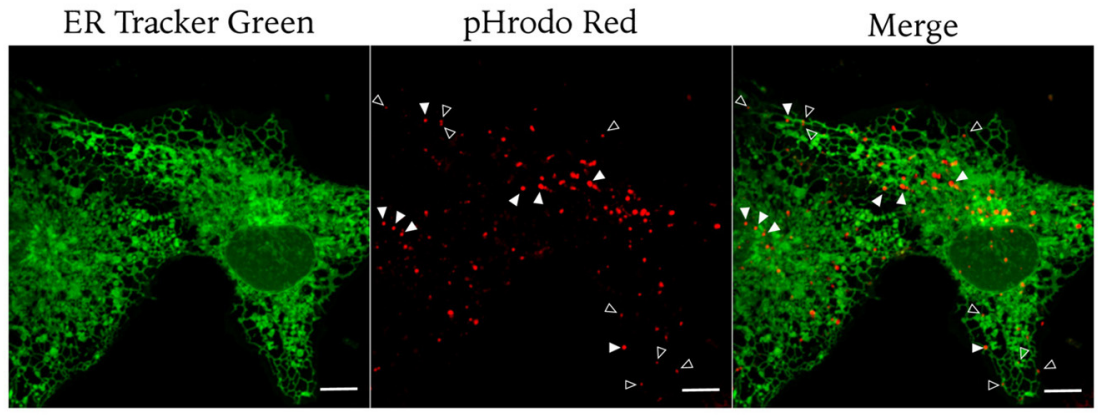

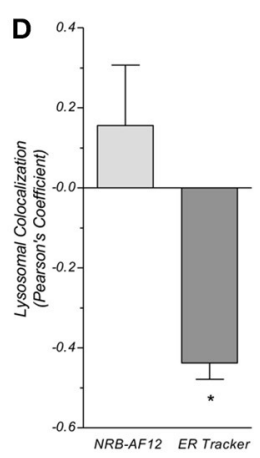

FIGURE 7 | Confocal live cell microphotographs of LX2 cells stained with the fluorescent dye for endosomal (empty arrowhead) and lysosomal (full arrowhead) compartments pHrodo red and (A) NRB-AF12 or (B) ER-Tr green. Magnification 60x; scale bar 10 $\mu$ m. (C,D) Co-localization of NRB-AF12 and ER-Tr Green with endosome and lysosome vesicles is shown as Pearson's coefficient $\left({ }^{\star} p<0.05 ; n \geq 10\right)$. 

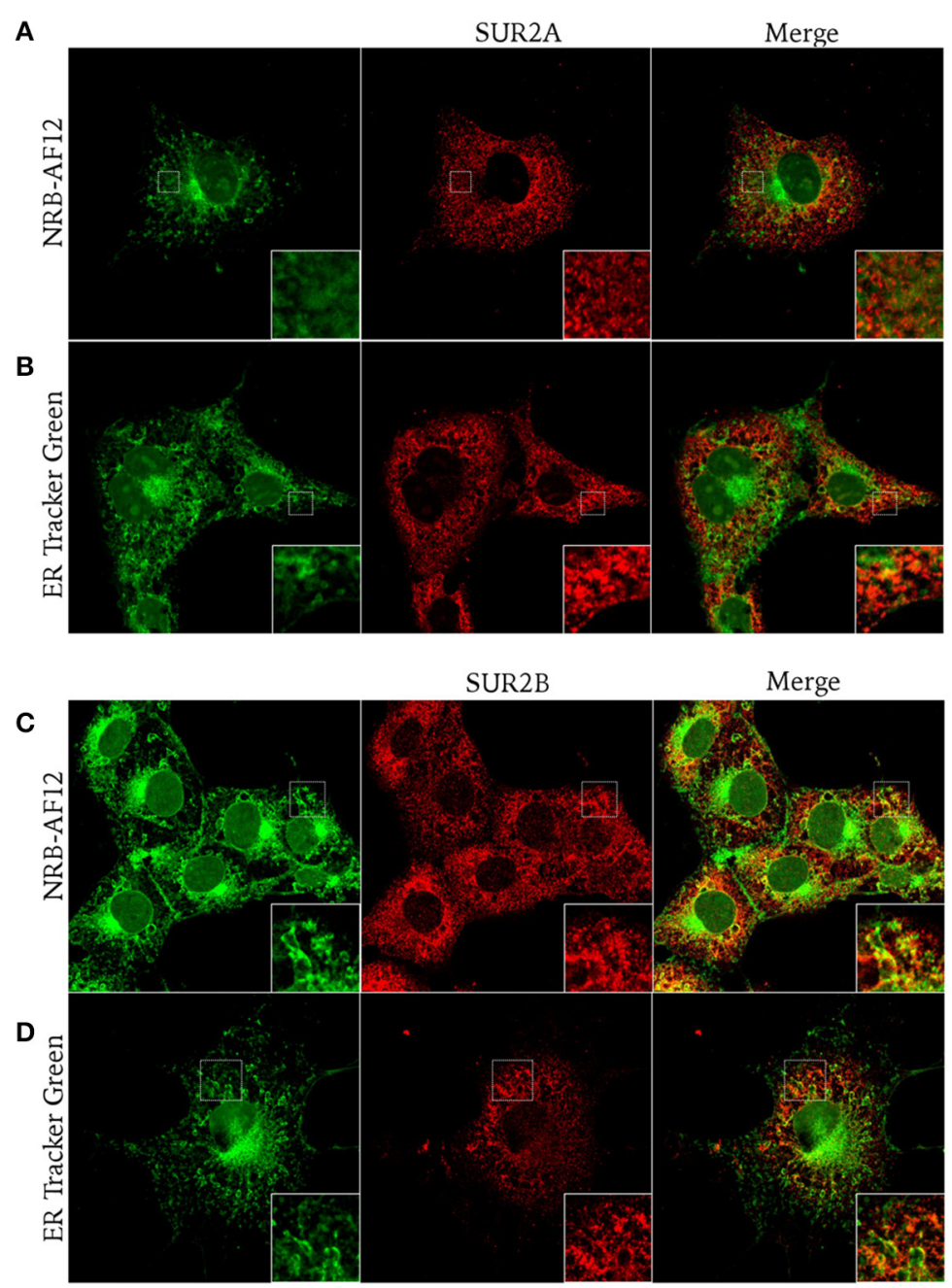
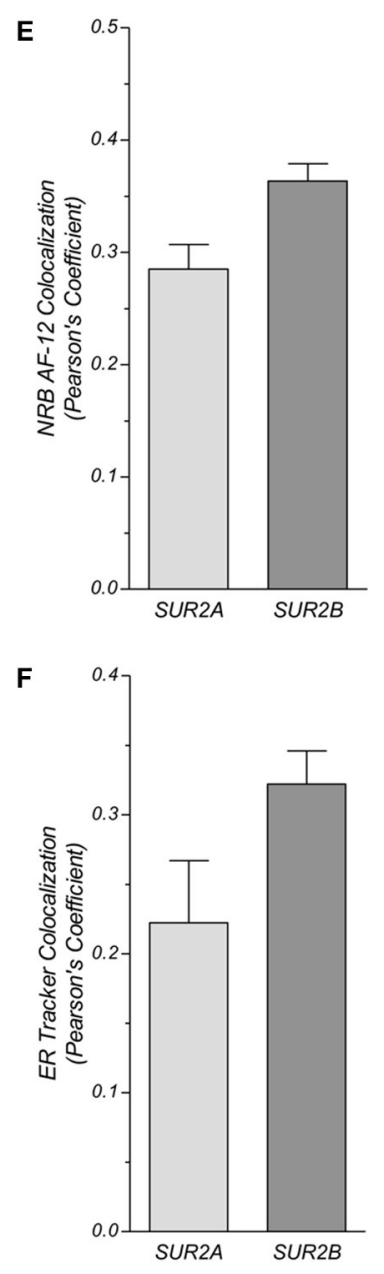

FIGURE 8 | (A,B) Confocal pictures of LX2 fixed cells immunostained for the KATP channels subunit SUR2A and counter-labeled with (A) NRB-AF12 or (B) ER-Tr green. (C,D) Immunostaining of LX2 cells for SUR2B subunit of $K_{\text {ATP }}$ channels; cells were counter-labeled with (C) NRB-AF12 or (D) ER-Tr green. Insets show magnification of the pictures. Magnification 60x; scale bar $10 \mu \mathrm{m}$. (E,F) Pearson's coefficient showing co-localization rate of (E) NRB-AF12 or (F) ER-Tr green with either SURs isoforms $(n \geq 15)$.

$-0.19-0.5$, for endosomes and lysosomes respectively; $n \geq 10$ ), indicating that not all endosomes/lysosomes vesicles were stained by the dye.

Since NRB-AF12 and ER-Tr showed the same cellular labeling pattern, we hypothesized a common target for these compounds. ER-Tr probes are conjugates of glibenclamide bearing different fluorophores, BODIPY FL (ER-Tr green) and BODIPY TR (ER$\operatorname{Tr}$ red). Glibenclamide is an antidiabetic drug belonging to the class of sulfonylureas that binds the sulfonylurea receptor (SUR) subunits of ATP-sensitive potassium channels (Proks et al., 2002). Accordingly, we therefore explored the likelihood of whether NRB could also target these SURs by analyzing the co-localization between NRB-AF12 and the 2 major subunits SUR2A and SUR2B. We focused our attention on these SUR isoforms because of their intracellular distribution (Bao et al., 2011) and the role of the plasmalemmal SUR2B in the regulation of vascular contraction (Morrissey et al., 2005; Teramoto, 2006; Jackson, 2008; Tinker et al., 2014). Our results indicate that in LX2 cells NRB-AF12 co-localized with both SUR2A and SUR2B, with a greater correlation for the latter (Pearson's coefficient: 0.28 \pm 0.02 and $0.36 \pm 0.01$, respectively for SUR2A and SUR2B; $n$ $\geq 10$ ) (Figures $\mathbf{8 A}, \mathbf{C}, \mathbf{E}$ ); comparable results were also obtained with ER-Tr (Pearson's coefficient: $0.22 \pm 0.04$ and $0.32 \pm 0.02$, respectively for SUR2A and SUR2B; $n \geq 10$ ) (Figure 8B,D,F). It is worth noting that the cellular distribution of NRB-AF12 and ER-Tr fluorescence was larger than that observed with SUR2, suggesting non-SUR2 additional targets for both dyes.

The overlapping fluorescence distributions of AF-12 and ER-Tr prompted us to investigate whether NRB and glibenclamide could compete with their respective fluorescent derivatives in LX2 cells. To this end, LX2 cells were pretreated with high concentrations $(100 \mu \mathrm{M})$ of either NRB 


\section{A}
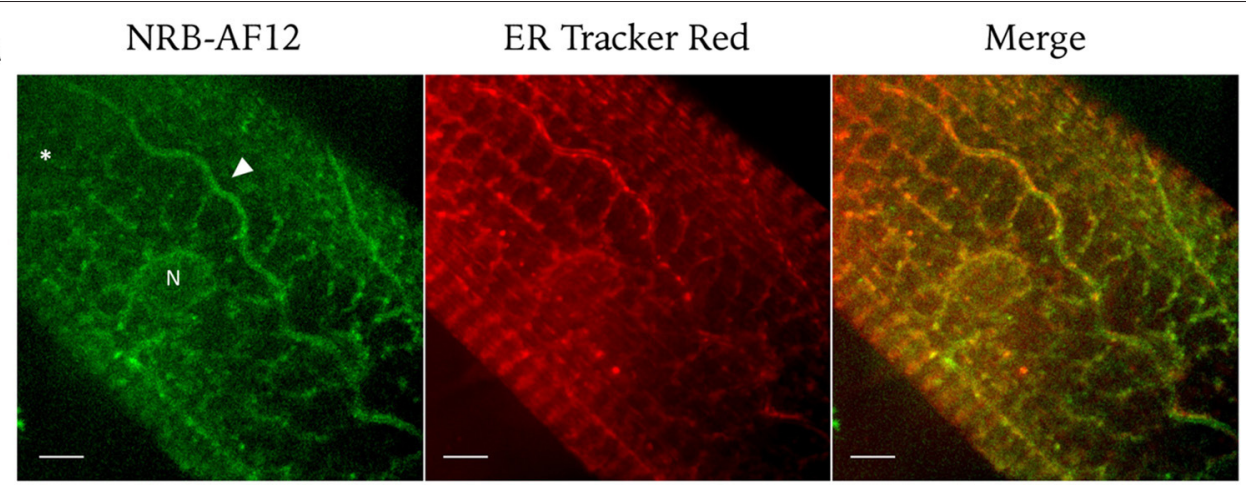

B
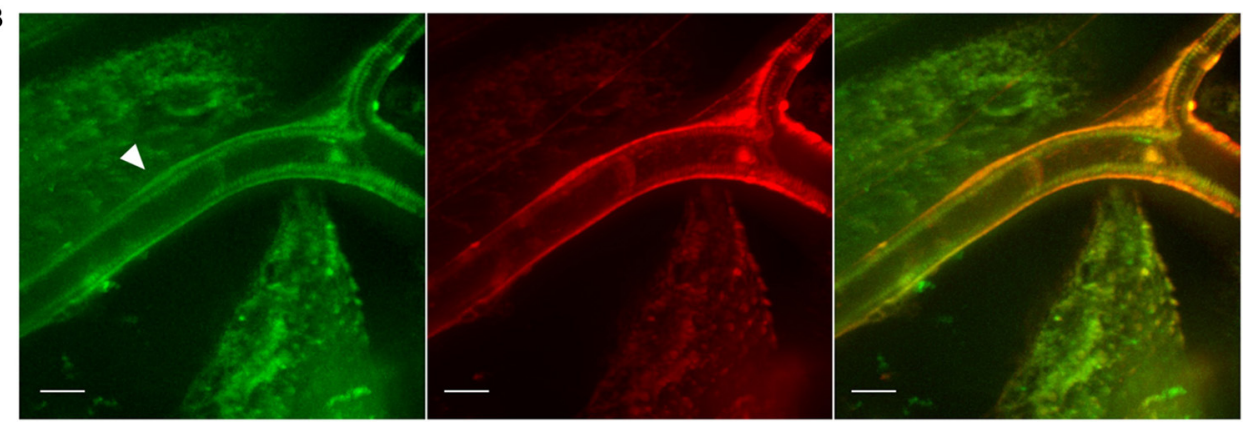

FIGURE 9 | Confocal live imaging of Drosophila (A) muscles and (B) tracheal system labeled with NRB-AF12 (green) and ER-Tr red (red). Both

fluorescent dyes, added to the dissected larva in HL3 physiological solution, show an overlapping pattern of distribution as highlight by the yellow signal of the merged images ( ${ }^{*}$ : muscle; white arrowhead: trachea; N: nucleus). Magnification 60x; scale bar $10 \mu \mathrm{m}$.

or glibenclamide, and then loaded with either NRB-AF12 or ER-Tr. Interestingly, pre-treatment with the nonlabeled compounds failed to prevent fluorescent labeling following addition of the fluorescent derivatives (data not shown).

To summarize the results concerning the cellular distribution of AF-12, we show in Figure 10 a single living LX2 cell, in which are detailed the subcellular organelles labeled by the dye.

We also explored the fluorescence features of NRB-AF12 in intact tissues of dissected larvae of Drosophila melanogaster. Third instar larvae were labeled with NRB-AF12 and ER-Tr dissolved in the hemolymph-like HL3 saline, added to the medium following dissection and imaged with an immersion objective. As shown in Figure 9, a bright fluorescence was observed when larvae were treated with the fluorescent probes: In vivo live imaging of $D$. melanogaster muscle fibers (Figure 9A) and tracheal system (Figure 9B) revealed a sarcoplasmic reticulum distribution of the dyes, with NRBAF12 and ER-Tr fluorescence significantly overlapping, as was observed in cell culture (Johnson et al., 2015). Finally, we investigated some physical properties of NRB-AF-12 such as penetration, internalization rate, retention time, washout time-course in living cells, as well as the induction of cytotoxicity, in order to establish the usefulness and reliability of the dye. Video 1 in Supplementary Material, shows that in living LX2 cells AF-12 is internalized in minutes and is retained in the cells for at least $3 \mathrm{~h}$ following its removal from the culture medium. Furthermore, re-exposure of the cells to dye, gave the same results, in terms of fluorescence distribution, compared to the first exposure. NRB-AF12 was apparently not toxic in both human and rat cell lines, even at concentrations much higher than those $(500 \mathrm{nM})$ utilized for labeling (Figures 11B-D).

\section{DISCUSSION}

This study was undertaken to verify if a fluorescent derivative of NRB could furnish information about the cellular target/s involved in the selective rat-specific and tissue-selective action of unlabeled NRB. To this end, we attached the NBD fluorophore to the NRB molecule. The NBD group is known to bleach very rapidly in respect to other commercially available fluorophores, nevertheless we decided to use NBD because of its relatively small size, in the attempt to minimize the risk of inducing a distortion of the chemical-physical properties of NRB. We compared the fluorescence distribution of NBD-NRB (NRBAF12) observed in NRB-sensitive cells (freshly isolated rat caudal artery myocytes) with that observed in NRB-insensitive cells (several cultured cell lines). Preliminary experiments conducted in our lab indicated that NRB-AF12 has the same speciesand tissue-specific contractile properties of unlabeled NRB 


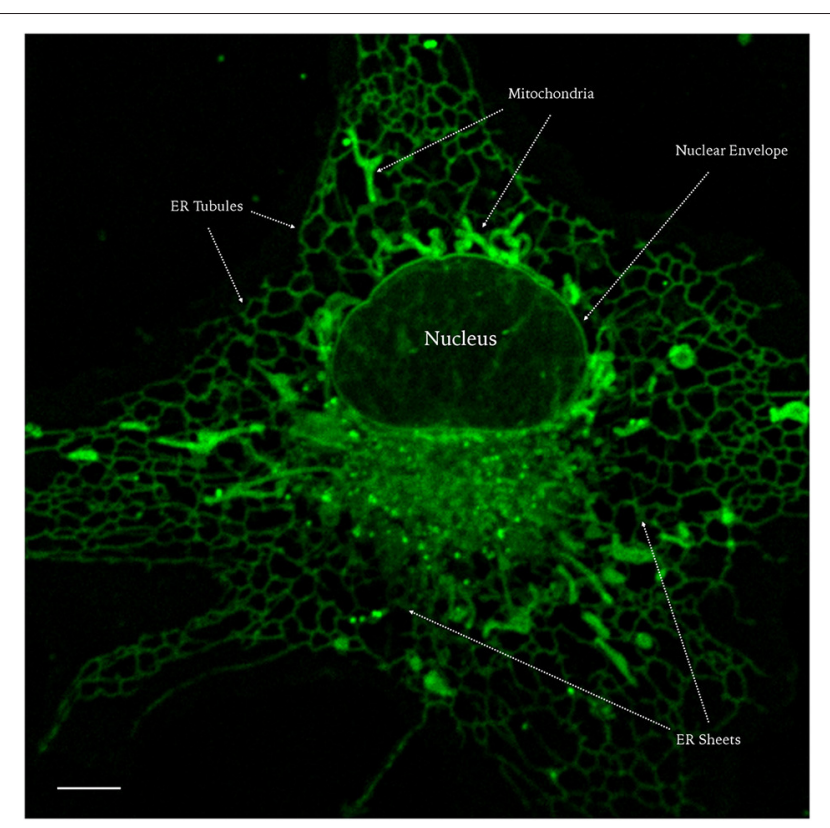

FIGURE 10 | Confocal live imaging of a LX2 cell stained with NRB-AF12 showing subcellular distribution of the fluorescent probe. Magnification 100x; scale bar $5 \mu \mathrm{m}$.

(manuscript in preparation), and therefore is a reliable tool for the purpose of this work.

There are two key observations:

1) In both NRB-sensitive and NRB-insensitive cells NRB-AF12 distributes intracellularly; however, only in the sensitive cells is fluorescence detected in the plasma membrane.

2) In all the cells investigated, NRB-AF12 fluorescence showed a pattern of distribution similar to that of ER-Tr.

Given that the cellular labeling patterns of NRB-AF12 and ER-Tr are near identical, it could be proposed that the two dyes share a common cellular target/s. ER-Tr is a BODIPY derivative of glibenclamide, a widely used antidiabetic drug belonging to the sulfonylurea family. Glibenclamide is a nonselective inhibitor of ATP-sensitive potassium channels (Proks et al., 2002), a multimeric protein complex consisting of four pore-lining inward rectifier $\alpha$ subunits $\left(K_{i r} 6.1 / 2\right)$ and four regulatory sulfonylurea-binding $\beta$ subunits (SUR1/2A/2B) that belong to the ATP-binding cassette family (Yokoshiki et al., 1998; Zerangue et al., 1999; Shi et al., 2005; Ng et al., 2010). Co-assembly of different $K_{i r}$ and SUR subunits generates ion channel combinations with different channel properties, and with different cell compartment or tissue distribution (Yokoshiki et al., 1998), such as the SUR $1 / K_{\mathrm{ir}} 6.2$ pancreatic type, the SUR2A/K $K_{\text {ir }} 6.2$ cardiac type and the SUR2B/K 6.1 vascular smooth muscle type. The ER-Tr and NRB-AF12 fluorescence characteristics may therefore reflect the cellular distribution of $\mathrm{K}_{\mathrm{ATP}}$ channels. Inhibition of plasma membrane ATP-sensitive potassium channels leads to an increased intracellular $\mathrm{K}^{+}$ concentration, plasma membrane depolarization, opening of voltage-dependent calcium channels, and increased intracellular $\mathrm{Ca}^{2+}$ concentration (Ko et al., 2008) that, in vascular smooth muscle, triggers the contractile process. It has been reported that vascular smooth muscle plasma membrane selectively expresses SUR2B subunits of $\mathrm{K}_{\text {ATP }}$ channels (Morrissey et al., 2005; Teramoto, 2006; Tinker et al., 2014). These data, together with the finding (this study) that NRB-AF12 localizes to the plasma membrane only in NRB-sensitive cells, might explain the species- and tissue-selective activity of NRB, by hypothesizing an inhibitory effect of the drug on rat-specific SUR2B-containing $\mathrm{K}_{\mathrm{ATP}}$ channels expressed on the plasma membrane of the rat peripheral artery myocytes. In contrast to this hypothesis is the fact that neither unlabeled NRB nor glibenclamide are able to displace NRB-AF12 or ER-Tr from their binding site, which presents the prospect of a different/additional site of action from/to $K_{\text {ATP }}$ channels. It also raises the question as to whether the fluorescently labeled compounds have the same binding characteristics of the corresponding unlabeled compounds. However, the lack of displacement is in itself not sufficient to rule out the possibility that NRB-AF12 does bind to $\mathrm{K}_{\mathrm{ATP}}$ channels, with there being at least two plausible explanations: (1) NRB-AF12 and NRB could bind to different sites within the SUR2B moiety, thus allowing the attachment of both compounds; (2) the fluorophore group of NRB-AF12 may have multiple binding sites preventing its displacement by unlabeled NRB. The existence of more than one binding site, at least for NRB-AF12, is supported by the fact that this dye, in contrast to ER-Tr, was able to label both endosomes and lysosomes. As with SUR2containing channels, NRB-AF12 appears to be similarly targeted to the endosomal/lysosomal pathway, supporting the idea that this compound can be recycled by endocytosis as has been shown for the $\mathrm{K}_{\mathrm{ATP}}$ channel subunits (Bao et al., 2011).

Live cell imaging represents an important technique in the study of biological processes; the use of fluorescent proteins or dyes provides an important tool for the in vivo visualization, in space, and time, of virtually any cellular mechanism or structure, avoiding artifacts or sample alteration that could occur with fixation methods. In this study we show that NRBAF12 is endowed with features that make this dye an eligible prototype of new fluorescent probes, alternatives to ER-Tr, for live cell imaging (Figure 10). Furthermore, in NRB-sensitive single rat vascular myocytes, this dye, due to its constriction effect (manuscript in preparation), could also be employed to study the morphologic changes that occur in labeled intracellular organelles, as well as in the plasma membrane, during the contractile process. Whatever the binding site/s for NRB-AF12, this dye shows a cellular distribution near identical to that of ER-Tr in real-time fluorescent imaging using different cultured cell lines and freshly isolated rat caudal artery myocytes. NRBAF12 labeling was also observed in fixed and permeabilized cells, allowing its use in immunocytochemistry co-localization experiments. In all cells tested, NRB-AF12 stained not only ER, but also other subcellular compartments such as Golgi apparatus, mitochondria, and organelles involved in the endocytic pathway (i.e., endosomes and lysosomes). NRB-AF12 internalization rate was extremely fast, since cell incubation with the fluorescent compound resulted in a well-defined meshwork staining of the 

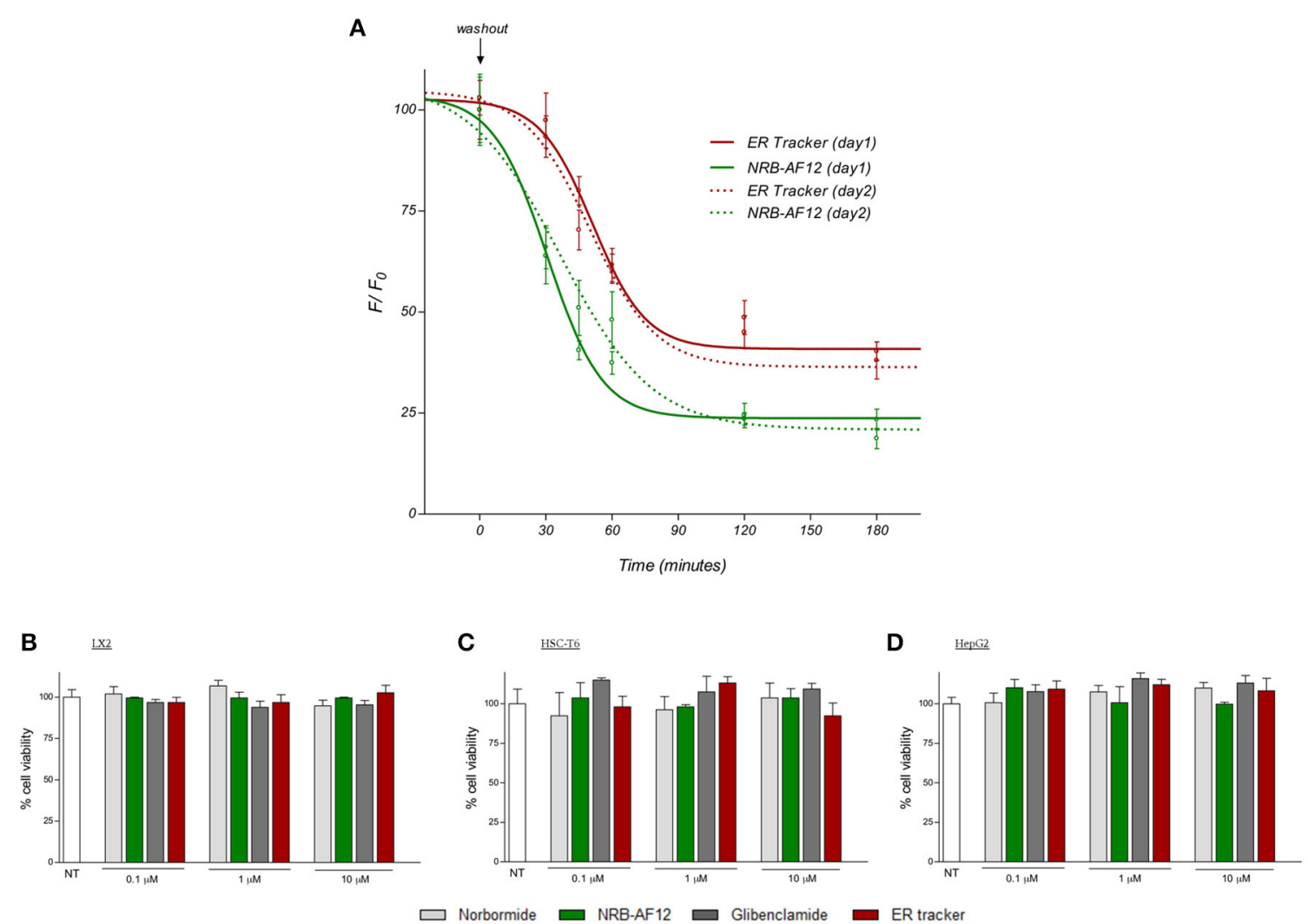

FIGURE 11 | (A) LX2 cells were incubated for 30 min with NRB-AF12 or ER-Tr green; after replacing the staining solution with probe-free medium, evaluation of NRB-AF12 and ER-Tr extent of fluorescent signal and photostability was performed. (B) LX2, (C) HSC-T6, and (D) HepG2 cells were treated for $24 \mathrm{~h}$ with increasing doses $(0.1,1$ and $10 \mu \mathrm{M})$ of NRB, NRB-AF12, glibenclamide or ER-Tr. Compounds toxicity was evaluated by trypan blue exclusion test of cell viability. NT, not treated cells.

cellular structures within a few minutes, and could be observed up to $3 \mathrm{~h}$ following its removal from the culture medium (Figure 11A). Another useful feature is that NRB-AF12 exhibited no apparent cytotoxicity, a serious disadvantage that often occurs using fluorescent probes for live cell imaging. Cell viability experiments demonstrated the dye to be biocompatible, having no harmful effects in the different cell lines (both human and rat) after 24 -h incubation, even at concentrations $(10 \mu \mathrm{M})$ much higher than those $(500 \eta \mathrm{M})$ needed to visualize cellular organelles (Figures 11B-D). Furthermore, the lack of cytotoxicity of NRBAF12 allows the same sample to be repeatedly stained with the dye (for example at different time points within an experiment), without morphological alteration of cell structures or cell death; concurrently, the ability of NRB to effectively label its cellular target is preserved on re-exposure to the dye (Figure 11A).

Finally, imaging experiments performed in dissected larvae of $D$. melanogaster demonstrated NRB-AF12 adaptability in complex biological systems. The live imaging of fly tissues showed that NRB-AF12 maintain the same subcellular distribution of ER-Tr also in vivo, supporting the theory of a common target. Moreover, we observed a significant signal in the Drosophila tracheal system where Drosophila Sur (Dsur) is highly expressed
(Nasonkin et al., 1999). Dsur, encodes a glibenclamidesensitive potassium channel and has been identified as the functional orthologue of the mammalian SUR2 (Kim and Rulifson, 2004). On the basis of these favorable properties, we propose NRB-AF12 as an alternative fluorescent dye to ER-Tr, and a new improved tool for labeling intracellular organelles.

In conclusion, this study presents evidence to demonstrate that NRB-AF12, a fluorescent derivative of the selective rat toxicant NRB, has a highly similar fluorescence distribution to ER-Tr, a fluorescent derivative of glibenclamide, a known $\mathrm{K}_{\mathrm{ATP}}$ channel inhibitor. On the basis of these results we hypothesize common cellular binding sites for NRB and glibenclamide that may potentially lead to common biological properties. Furthermore, we propose NRB-AF12 as a prototype for the development of new fluorescent probes selective for intracellular structures/organelles. Studies are in progress in our lab to investigate these aspects.

\section{AUTHOR CONTRIBUTIONS}

$\mathrm{CD}$ and GO contributed equally to this work. SB, CD, and MP conceived the study. AFe, MB, DR, BH, and 
GR designed and performed synthesis of NRB-AF12. $\mathrm{CD}, \mathrm{GO}, \mathrm{GM}, \mathrm{FF}, \mathrm{AFo}, \mathrm{GC}$, and $\mathrm{SD}$ designed and performed experiments. $\mathrm{SB}, \mathrm{CD}$, and $\mathrm{GO}$ analyzed and interpreted data. $\mathrm{SB}, \mathrm{CD}, \mathrm{GO}, \mathrm{DR}$, and $\mathrm{BH}$ wrote the manuscript. All authors approved the final version of the manuscript.

\section{FUNDING}

This study was supported by the University of Padova, project $n$. $148125 / 14$.

\section{REFERENCES}

Bao, L., Hadjiolova, K., Coetzee, W. A., and Rindler, M. J. (2011). Endosomal KATP channels as a reservoir after myocardial ischemia: a role for SUR2 subunits. Am. J. Physiol. Heart Circ. Physiol. 300, H262-H270. doi: 10.1152/ajpheart.00857.2010

Bova, S., Cima, L., Golovina, V., Luciani, S., and Cargnelli, G. (2001). Norbormide: a calcium entry blocker with selective vasoconstrictor activity in rat peripheral arteries. Cardiovasc. Drug Rev. 19, 226-233. doi: 10.1111/j.1527-3466.2001. tb00067.x

Bova, S., Trevisi, L., Debetto, P., Cima, L., Furnari, M., Luciani, S., et al. (1996). Vasorelaxant properties of norbormide, a selective vasoconstrictor agent for the rat microvasculature. Br. J. Pharmacol. 117, 1041-1046.

Cao, Y., Min, C., Acharya, S., Kim, K.-M., and Cheon, S. H. (2016). Design, synthesis and evaluation of bitopic arylpiperazinephenyl-1,2,4-oxadiazoles as preferential dopamine D3 receptor ligands. Bioorg. Med. Chem. 24, 191-200. doi: $10.1016 /$ j.bmc.2015.12.002

Cavalli, M., Omiciuolo, L., Cargnelli, G., Cima, L., Hopkins, B., and Bova, S. (2004). Distribution of the vasoconstrictor and vasorelaxant effects of norbormide along the vascular tree of the rat. Life Sci. 75, 2157-2165. doi: 10.1016/j.lfs.2004.04.022

Clarke, E. G. (1965). Identification of norbormide, a new rattus specific rodenticide. J. Pharm. Pharmacol. 17, 126.

Fusi, F., Manetti, F., Durante, M., Sgaragli, G., and Saponara, S. (2016). The vasodilator papaverine stimulates L-type $\mathrm{Ca} 2+$ current in rat tail artery myocytes via a PKA-dependent mechanism. Vascul. Pharmacol. 76, 53-61. doi: 10.1016/j.vph.2015.11.041

Fusi, F., Saponara, S., Sgaragli, G., Cargnelli, G., and Bova, S. (2002). Ca(2+) entry blocking and contractility promoting actions of norbormide in single rat caudal artery myocytes. Br. J. Pharmacol. 137, 323-328. doi: 10.1038/sj.bjp. 0704877

Jackson, W. F. (2008). Vanishing act: protein kinase C-dependent internalization of adenosine 5'-triphosphate-sensitive $\mathrm{K}+$ channels. Hypertension 52, 470-472. doi: 10.1161/HYPERTENSIONAHA.108.112425

Johnson, A. E., Shu, H., Hauswirth, A. G., Tong, A., and Davis, G. W. (2015). VCP-dependent muscle degeneration is linked to defects in a dynamic tubular lysosomal network in vivo. eLife 4:e07366. doi: 10.7554/eLife.07366

Kim, S. K., and Rulifson, E. J. (2004). Conserved mechanisms of glucose sensing and regulation by Drosophila corpora cardiaca cells. Nature 431, 316-320. doi: 10.1038/nature02897

Ko, E. A., Han, J., Jung, I. D., and Park, W. S. (2008). Physiological roles of K+ channels in vascular smooth muscle cells. J. Smooth Muscle Res. 44, 65-81. doi: $10.1540 /$ jsmr.44.65

Morrissey, A., Rosner, E., Lanning, J., Parachuru, L., Dhar Chowdhury, P., Han, S., et al. (2005). Immunolocalization of KATP channel subunits in mouse and rat cardiac myocytes and the coronary vasculature. BMC Physiol. 5:1. doi: 10.1186/1472-6793-5-1

Nasonkin, I., Alikasifoglu, A., Ambrose, C., Cahill, P., Cheng, M., Sarniak, A., et al. (1999). A novel sulfonylurea receptor family member expressed in the embryonic Drosophila dorsal vessel and tracheal system. J. Biol. Chem. 274, $29420-29425$.

\section{ACKNOWLEDGMENTS}

We thank Prof. Stefano Fiorucci (University of Perugia) for kindly gifting LX2 and HSC-T6 cells and Prof. Giuseppe Zagotto (University of Padova), for the determination of the fluorescence spectra of NRB-AF12.

\section{SUPPLEMENTARY MATERIAL}

The Supplementary Material for this article can be found online at: http://journal.frontiersin.org/article/10.3389/fphar. 2016.00315

Ng, K.-E., Schwarzer, S., Duchen, M. R., and Tinker, A. (2010). The intracellular localization and function of the ATP-sensitive K+ channel subunit Kir6.1. J. Membr. Biol. 234, 137-147. doi: 10.1007/s00232-010-9241-x

Poos, G. I., Mohrbacher, R. J., Carson, E. L., Paragamian, V., Puma, B. M., Rasmussen, C. R., et al. (1966). Structure-activity studies with the selective rat toxicant norbormide. J. Med. Chem. 9, 537-540.

Proks, P., Reimann, F., Green, N., Gribble, F., and Ashcroft, F. (2002). Sulfonylurea stimulation of insulin secretion. Diabetes 51(Suppl. 3), S368-S376. doi: 10.2337/diabetes.51.2007.S368

Ricchelli, F., Dabbeni-Sala, F., Petronilli, V., Bernardi, P., Hopkins, B., and Bova, S. (2005). Species-specific modulation of the mitochondrial permeability transition by norbormide. Biochim. Biophys. Acta 1708, 178-186. doi: 10.1016/j.bbabio.2005.03.002

Roszkowski, 1965\#\#\#Roszkowski, A. P. (1965). The pharmacological properties of norbormide, a selective rat toxicant. J. Pharmacol. Exp. Ther. 149, 288-299.

Shi, N.-Q., Ye, B., and Makielski, J. C. (2005). Function and distribution of the SUR isoforms and splice variants. J. Mol. Cell. Cardiol. 39, 51-60. doi: 10.1016/j.yjmcc.2004.11.024

Teramoto, N. (2006). Physiological roles of ATP-sensitive K+ channels in smooth muscle. J. Physiol. 572(Pt 3), 617-624. doi: 10.1113/jphysiol.2006.105973

Tinker, A., Aziz, Q., and Thomas, A. (2014). The role of ATP-sensitive potassium channels in cellular function and protection in the cardiovascular system. Br. J. Pharmacol. 171, 12-23. doi: 10.1111/bph.12407

Yokoshiki, H., Sunagawa, M., Seki, T., and Sperelakis, N. (1998). ATP-sensitive $\mathrm{K}+$ channels in pancreatic, cardiac, and vascular smooth muscle cells. Am. J. Physiol. 274(1Pt 1), C25-C37.

Zerangue, N., Schwappach, B., Jan, Y. N., and Jan, L. Y. (1999). A new ER trafficking signal regulates the subunit stoichiometry of plasma membrane K(ATP) channels. Neuron 22, 537-548.

Zulian, A., Petronilli, V., Bova, S., Dabbeni-Sala, F., Cargnelli, G., Cavalli, M., et al. (2007). Assessing the molecular basis for rat-selective induction of the mitochondrial permeability transition by norbormide. Biochim. Biophys. Acta 1767, 980-988. doi: 10.1016/j.bbabio.2007.04.002

Zulian, A., Sileikytè, J., Petronilli, V., Bova, S., Dabbeni-Sala, F., Cargnelli, G., et al. (2011). The translocator protein (peripheral benzodiazepine receptor) mediates rat-selective activation of the mitochondrial permeability transition by norbormide. Biochim. Biophys. Acta 1807, 1600-1605. doi: 10.1016/j.bbabio.2011.08.007

Conflict of Interest Statement: The authors declare that the research was conducted in the absence of any commercial or financial relationships that could be construed as a potential conflict of interest.

Copyright (c) 2016 D’Amore, Orso, Fusi, Pagano, Miotto, Forgiarini, De Martin, Castellani, Ribaudo, Rennison, Brimble, Hopkins, Ferrarese and Bova. This is an open-access article distributed under the terms of the Creative Commons Attribution License (CC BY). The use, distribution or reproduction in other forums is permitted, provided the original author(s) or licensor are credited and that the original publication in this journal is cited, in accordance with accepted academic practice. No use, distribution or reproduction is permitted which does not comply with these terms. 